\title{
A compreensão da comunidade joanina em Raymond E. Brown
}

Orientador: Prof. Isidoro Mazzarolo

Pesquisador: Douglas Galdino do Nascimento

Fonte: $\mathrm{CNPq}$

\section{Introdução}

Comunidade é um conjunto de pessoas que vivem no mesmo lugar, sob uma mesma liderança e compartilham da mesma herança cultural e histórica, praticando a mesma crença ou ideal, exercem atividades afins, com características especificas e individualizantes e se caracterizam pela forte coesão baseada no consenso espontâneo dos indivíduos.

\section{Objetivos}

Estudar os conceitos e compreensão da comunidade joanina na linha de pensamento teológico de Raymond Brown.

Resgatar os ensinamentos de Jesus no seio da vivência e da experiência de fé, a partir da Literatura Joanina. 